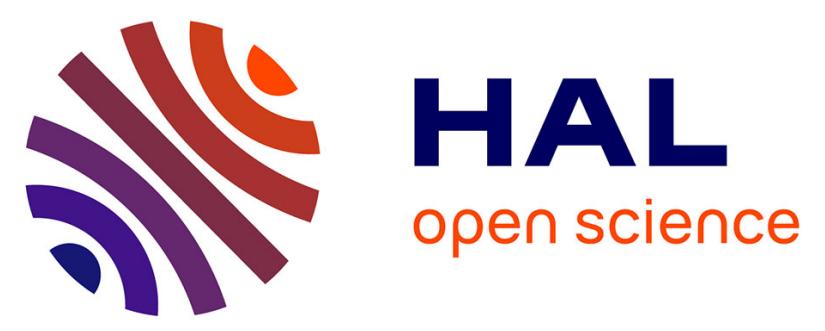

\title{
Pottery Firing Structures in the Early Mediterranean: Micromorphological Evidence and Archaeological Data from Middle Neolithic Kouphovouno (Southern Greece)
}

Christèle Ballut, Josette Renard, William G. Cavanagh, Raphaël Orgeolet

\section{To cite this version:}

Christèle Ballut, Josette Renard, William G. Cavanagh, Raphaël Orgeolet. Pottery Firing Structures in the Early Mediterranean: Micromorphological Evidence and Archaeological Data from Middle Neolithic Kouphovouno (Southern Greece). European Journal of Archaeology, 2017, 20 (01), pp.98119. 10.1017/eaa.2016.4 . hal-01472519

HAL Id: hal-01472519

https://hal.science/hal-01472519

Submitted on 25 Feb 2021

HAL is a multi-disciplinary open access archive for the deposit and dissemination of scientific research documents, whether they are published or not. The documents may come from teaching and research institutions in France or abroad, or from public or private research centers.
L'archive ouverte pluridisciplinaire HAL, est destinée au dépôt et à la diffusion de documents scientifiques de niveau recherche, publiés ou non, émanant des établissements d'enseignement et de recherche français ou étrangers, des laboratoires publics ou privés. 


\title{
Pottery Firing Structures in the Early Mediterranean: Micromorphological Evidence and Archaeological Data from Middle Neolithic Kouphovouno (Southern Greece)
}

\author{
Christèle Ballut ${ }^{1}$, Josette Renard ${ }^{2}$, William G. Cavanagh ${ }^{3}$ \\ and Raphä̈l Orgeolet ${ }^{4}$ \\ ${ }^{1}$ CNRS, Universities of Paris $I$ and $X$, France \\ ${ }^{2}$ University of Montpellier III, France \\ ${ }^{3}$ University of Nottingham, $U K$ \\ ${ }^{4}$ Aix Marseille University, CNRS, Ministry of Culture $\mathcal{E}^{2}$ Communication, LAMPEA, \\ Aix-en-Provence, France
}

Excavations at Kouphovouno (Laconia, Greece) have revealed burnt deposits associated with firing structures. The 'millefeuille' (vanilla slice) observed was composed of alternating layers of burnt red aggregates and white carbonate. Their description, micromorphological study, and contrast with a more standard structure of the Middle Neolithic allow us to interpret the layers as belonging to a structure for firing pottery: a covered clamp. This study has clarified its method of construction, operation, and use within a domestic context. After heating and cooking, the production of pottery and lime was one of the pyrotechnological activities most consumptive of energy among Neolithic communities, yet direct evidence for firing installations has been elusive. A new approach to the problem of locating pottery firing sites is presented here. The firing of pottery seems the most likely use for this type of structure, though the production of lime is also discussed.

Keywords: Neolithic, Greece, covered clamp, earth construction, micromorphology

\section{INTRODUCTION}

The aim of this article is to alert archaeologists to traces that might indicate early firing installations and to the importance of micromorphology for decoding their remains.

The effects of fire are among the observations most commonly made in archaeological reports, as the use of fire was so widespread. Its universal presence has led to a rather casual treatment of the remains left by fire and their confounding one with another, while the limited methodologies employed for their investigation has hampered informed analysis. Micromorphology, only rarely employed up to now on the sorts of remains discussed here (see GermainVallée et al., 2011), offers new perspectives for their interpretation; this applies in particular to our example of a find from the Middle Neolithic (MN hereafter) deposits at Kouphovouno in Laconia in southern Greece.

Neolithic firing structures have usually been classified according to function and there is a tradition of distinguishing hearths 
and cooking ovens from other installations, among which figure pottery kilns and limekilns. Fired pottery has now been traced back to some $15,000-18,000$ years ago in China (Boaretto et al., 2009) and 12,000 years in Africa (Huysecom et al., 2009), so the manufacture of pottery has long lost its primacy in defining Neolithic economies. Yet the scale of lime burning and pottery firing in the Neolithic was substantial, if second to cooking and heating in the consumption of fuel. The firing of lime, mainly for plaster floors and walls, was significant in the Near East already by the ninth millennium cal BC (Goren \& Goring-Morris, 2008), and pottery began to grow in importance from the seventh millennium, extending into the Aegean by $6500 \mathrm{cal} \mathrm{BC}$ and gradually thereafter into Europe. Furthermore, the quality and variety of pottery also increased: in the Levant and Mesopotamia the rather primitive wares of the seventh millennium gave way, around 6100-5800 cal BC, to the fine, elaborately decorated pottery of the Halaf and Hassuna styles (Moorey, 1994: 149-51) and a similar progression can be recognized in Anatolia (e.g. Çilingiroğlu, 2012) and Greece (e.g. Perlès, 2001: 210-20). The demands of these industries (lime plaster and pottery) in terms of fuel, material, and labour were therefore considerable. The remains of firing installations for quicklime have been identified at one or two sites, possibly at Çatal Höyük (Cessford, 2007) and notably at Kfar HaHoresh (Goren \& Goring-Morris, 2008). Updraft pottery kilns dating to around $6000 \mathrm{cal} \mathrm{BC}$ have been found at Yarim Tepe in Iraq (Hansen Streily, 2000; Petrova, 2012) and at a number of other Mesopotamian sites-Hansen Streily (2000) has assembled details of eighty-nine kilns at fifteen sites of the seventh to fifth millennia cal BC. It has been suggested tentatively that features such as the ash-filled pits of Tell Sabi Abyad I in Syria may have been used to fire the ceramics from the site (van As et al., 2004: 104-05). For Greece, it has been proposed that kilns were present at Imvrou Pigadi in Thessaly (KyparissiApostolika, 2012; Aidona et al., 2014); complete and unused vessels were recovered there within the burnt deposits from the kilns and hundreds of clay fragments with reed impressions seem to have come from the kilns' mantle. For the Late Neolithic, a 'kiln-like' structure has been noted at Kryoneri (Malamidou, 2007), at the complex S8 in Dimini, and installations at Stavroupolis and Limenaria have also been identified (discussion with references in Souvatzi, 2008: 181-82). Other kinds of installation are sometimes mentioned, notably bonfire and pit-firing (Gimbutas et al., 1989, for Middle Neolithic Achilleion; Yiouni, 1996: 69, for Early Neolithic Nea Nikomedeia), but none of these cases has been argued conclusively. Pots may have been fired away from the settlements at small temporary sites, unrecognized because of their small size (Loughlin, 2010: 34-35). Here, we argue that pottery firing installations are to be found on occupation sites, but have not been recognized as such.

\section{The Site of Kouphovouno}

The site of Kouphovouno lies on the outskirts of Sparta in southern Greece (Cavanagh et al., 2004; 2007; Mee et al., 2014) (Figure 1). It extends over some 4-5 ha and the MN deposits have been excavated to a depth of $3 \mathrm{~m}$. First excavated by Otto Wilhelm von Vacano in 1941 (Renard, 1989), it was reopened in 2001, after a survey and study in 1999-2000 (Cavanagh et al., 2004). Kouphovouno was first occupied in the MN (Figure 2), in the phase equivalent to Franchthi FCP 2.3 (Mee et al., 2014). Occupation continued through the Late Neolithic and during the Early Bronze Age and, more sporadically, thereafter. 


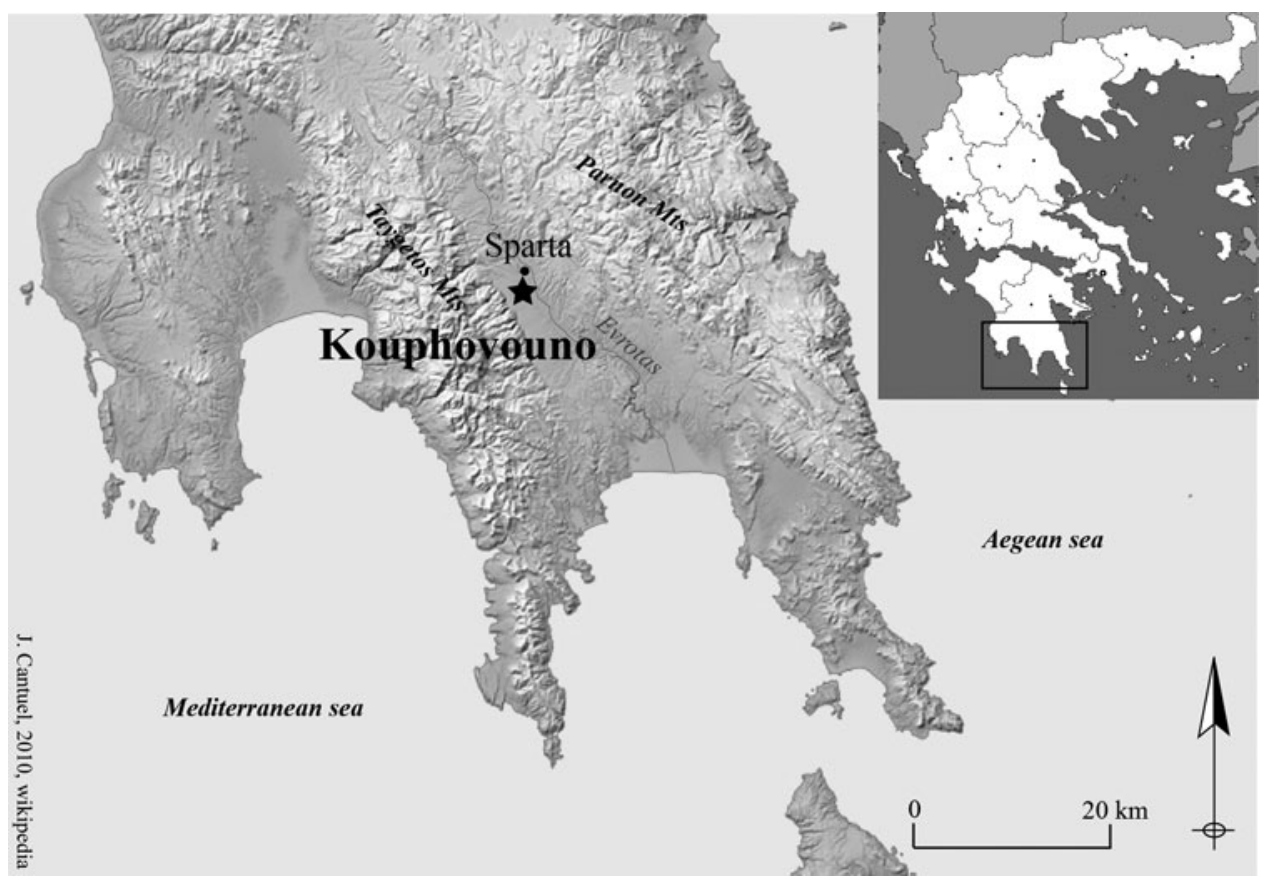

Figure 1. Geographical location of Kouphovouno in Laconia, Peloponnese (Jean Cantuel, after Rivals et al., 2011).

Five seasons of excavation between 2001 and 2006 recovered well-preserved $\mathrm{MN}$ habitation remains in two areas: Area $\mathrm{C}$, at the top of the tell, and Area G, on its southern slope. In both areas, the last phase of $\mathrm{MN}$ occupation is well represented by habitation remains, some of which lay undisturbed by later occupation immediately below the ploughsoil. The contexts of interest here come from Area $\mathrm{C}$ and date to the last $\mathrm{MN}$ phase. Based on AMS radiocarbon dating of seeds from contemporary stratigraphic units, the contexts belonging to the latest period of the firing structure-the focus of this article-range in date between c. 5640 and $5500 \mathrm{cal} \mathrm{BC}$ (Mee et al., 2014).

The pottery repertoire includes a variety of jars, bowls, and pedestalled bowls, normally painted and generally large in size (over half with a capacity greater than 1 litre); a number of specialized cooking pots were also produced (Mee, 2007: 201-10). The great majority of $\mathrm{MN}$ pottery in the Peloponnese is called 'Urfirnis' (from the German meaning primitive varnish) and in our MN levels (summarized in Mee et al., 2014: fig. 12, contexts C0837G2009) between 92 per cent and 100 per cent of all the recorded pottery consisted of Urfirnis. The ware has a lustrous paint on the outer and inner surfaces of the pots: monochrome, decorated with geometric motifs, or with 'scribble burnish'. The skill and technical mastery required for Urfirnis pottery was of a high order, and the elaborate chaine opératoire required for its manufacture has been brought out by Vitelli (1993: 199-204). She has also argued that at Franchthi Cave $\mathrm{MN}$ potters used large bottomless vessels as a portable, re-usable part of the kiln to fire their pots (Vitelli, 1997: 32). 


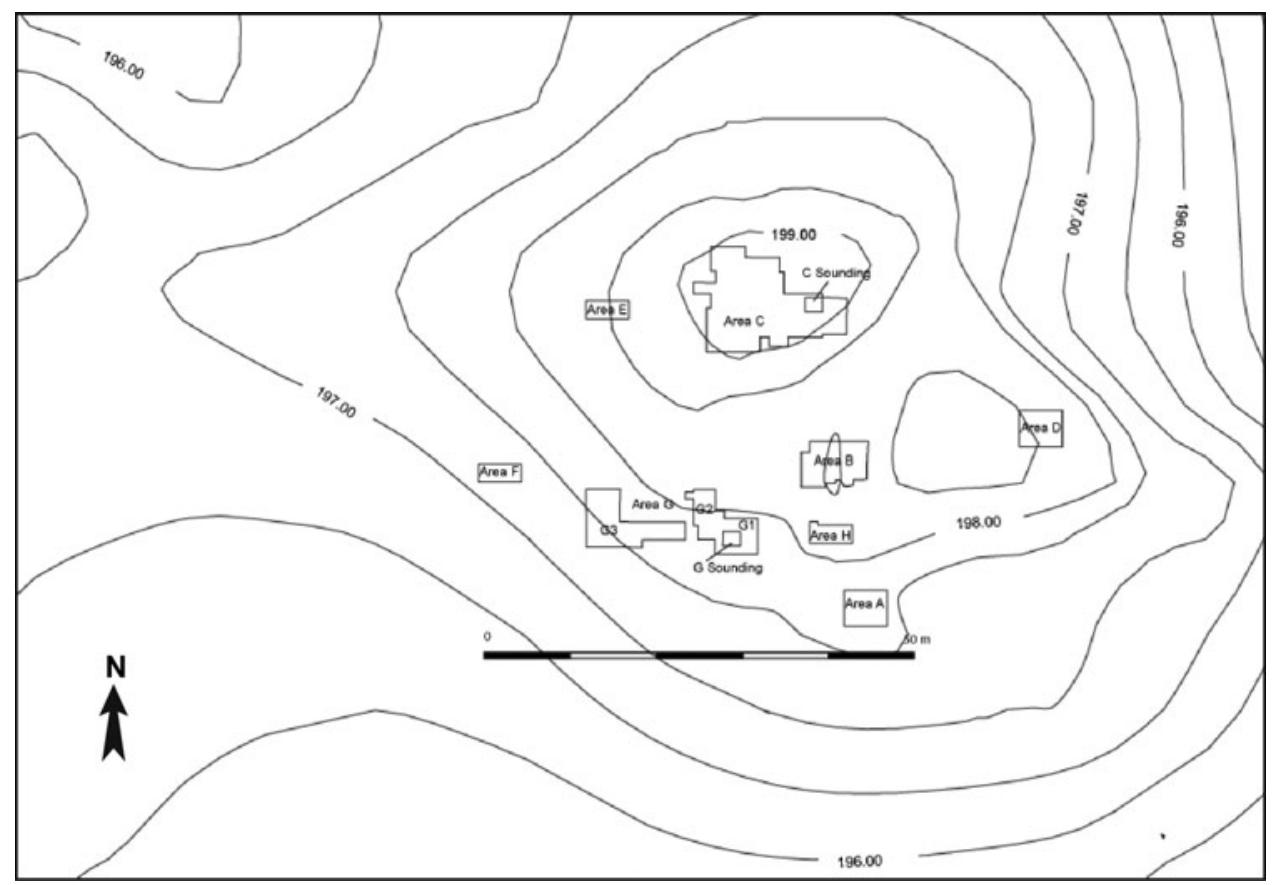

Figure 2. Site map of the archaeological excavations at Kouphovouno (drawing: W. Cavanagh).

\section{Field Description of the 'Millefeuille'}

At Kouphovouno, in a sounding in Area $\mathrm{C}$ at the top of the tell, within an open-air courtyard set between the remains of buildings (Figure 3), a series of superimposed stratified contexts was found. It was labelled 'millefeuille' (vanilla slice) at the time of excavation and its interpretation was not immediately clear. It consisted of a series of red, purple, or orange layers measuring $2-7 \mathrm{~cm}$ in thickness (contexts $1021=1861,1035,1036,1038,1044$, $1060=1862,1863,1067,1072)$ between which were interspersed whitish layers 0.5-1 cm thick (contexts 1020, 1028, 1061), except at the bottom of the sounding, where they reached $4 \mathrm{~cm}$ in thickness (contexts 1065, 1069) (Figure 4.1).

The total extent of this area, oval in shape, measured roughly $2 \mathrm{mE}-\mathrm{W} \times 3 \mathrm{~m}$ $\mathrm{N}-\mathrm{S}$, some $4.7 \mathrm{~m}^{2}$. It was situated in a large open-air courtyard measuring roughly $6.5 \mathrm{~m}$ $\mathrm{E}-\mathrm{W} \times 4 \mathrm{~m} \mathrm{~N}-\mathrm{S}$, between Structures $\mathrm{C} 1$ to the north, $\mathrm{C} 2$ to the north-west, $\mathrm{C} 3$ to the west, and $\mathrm{C} 4$ to the east-all probably domestic buildings. The firing area was bounded to the south by a stone wall, $0.2 \mathrm{~m}$ wide, excavated to a height of $0.3 \mathrm{~m}$ and over a length of $0.6 \mathrm{~m}$; the wall was coated with clay and a lime wash on its upper part including its top. To the north, it was separated from Structure $\mathrm{C} 1$ by an accumulation of layers of pebbles and reddened sediment, set regularly one over another. To the east it was separated from Structure $\mathrm{C} 4$ by contexts 1056 and 1059, an area covered with sherds, fragments of limestone, limestone cobbles (some of which were shattered), fragments and slabs of burnt lime plaster, and reddened sediment probably dating to the last phase of use of the 'millefeuille' area (Figure 4.3). To the west, a line of stones running NE-SW was uncovered over about $1.5 \mathrm{~m}$ starting from the corner of Structure 


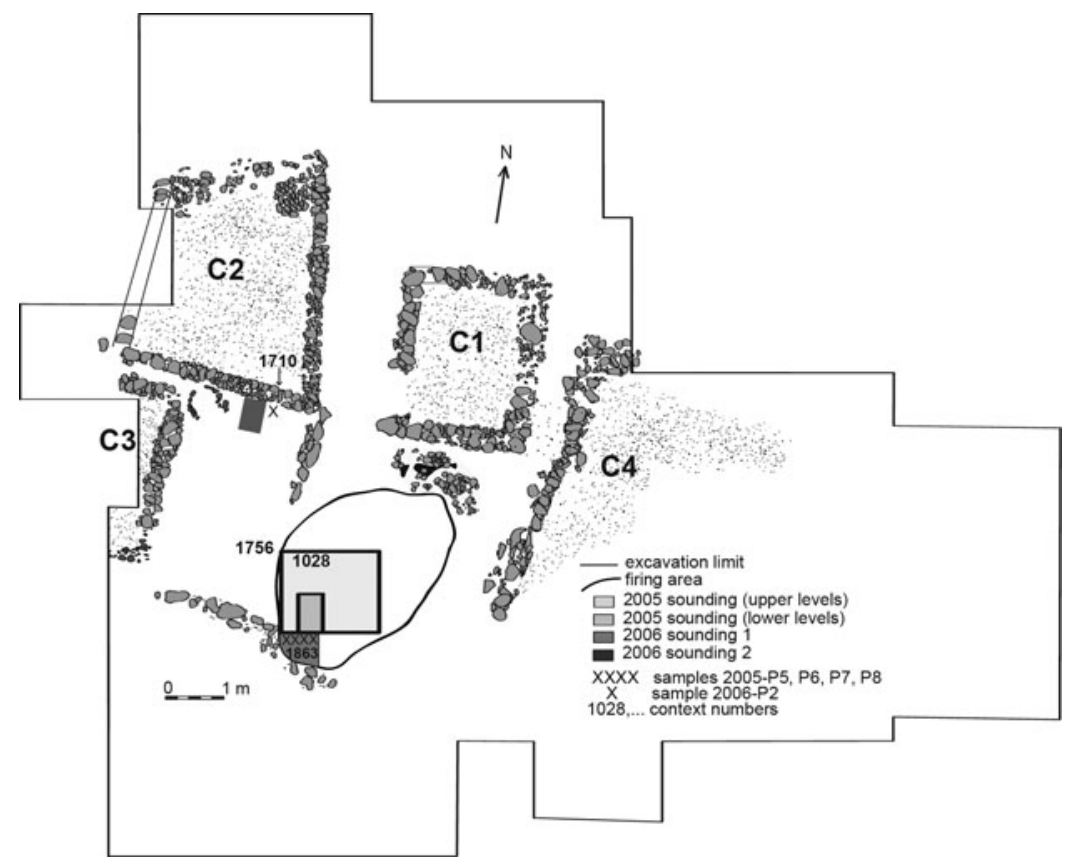

Figure 3. Plan of the building remains of the penultimate $M N$ construction phase in Area $C$ (drawing: R. Orgeolet and J.P. Renard).

$\mathrm{C} 2$ and separating the firing area from the western part of the courtyard, which was probably given over to cooking activities as indicated by the presence of ovens/hearths, pottery containers broken in situ, and stone tools including some saddle querns. In this part of Area $\mathrm{C}$ the $\mathrm{MN}$ deposits were not disturbed by later occupation. Finally it is worth mentioning the presence, to the north of Structure 1, of a large rubbish pit (the 'poubelle' or rubbish bin) whose use was evidently contemporary with the formation of the 'millefeuille'. It contained large quantities of animal bones, much Urfirnis pottery, coarse domestic wares including 'husking trays' and storage vessels, many chipped stone artefacts, some bone and stone tools, shell beads, and stone ornaments. There were traces of burnt clay and charcoal.

In 2005, the contexts forming the upper deposits of the firing area were excavated over an area of $1 \times 1.5 \mathrm{~m}$, but the time required to reveal the different layers as finely as possible constrained us to reduce the part excavated to $0.6 \times 0.4 \mathrm{~m}$ (Figure 4.1). By close of excavation in this sounding it was not clear whether we had reached the base of the feature. It was, however, possible to recognize a significant correspondence between certain layers of the 'millefeuille' and floors in the courtyard to the west, for example the top of floor 1756 in the courtyard continued context 1028 of the 'millefeuille', and the top of level 1753/54 abutted context 1020 of the 'millefeuille' (Table 1, Supplementary Data (SD), and Figure 8).

In 2006 an extension measuring $0.6 \times$ $0.4 \mathrm{~m}$ was opened towards the south of the 'millefeuille' down to the uppermost of the thick whitish deposits (Figure 4.2). The excavated units were much less precise than in 2005 and a single context of 2006 often combined several contexts of 2005 (see relationships in Table 1, SD). 

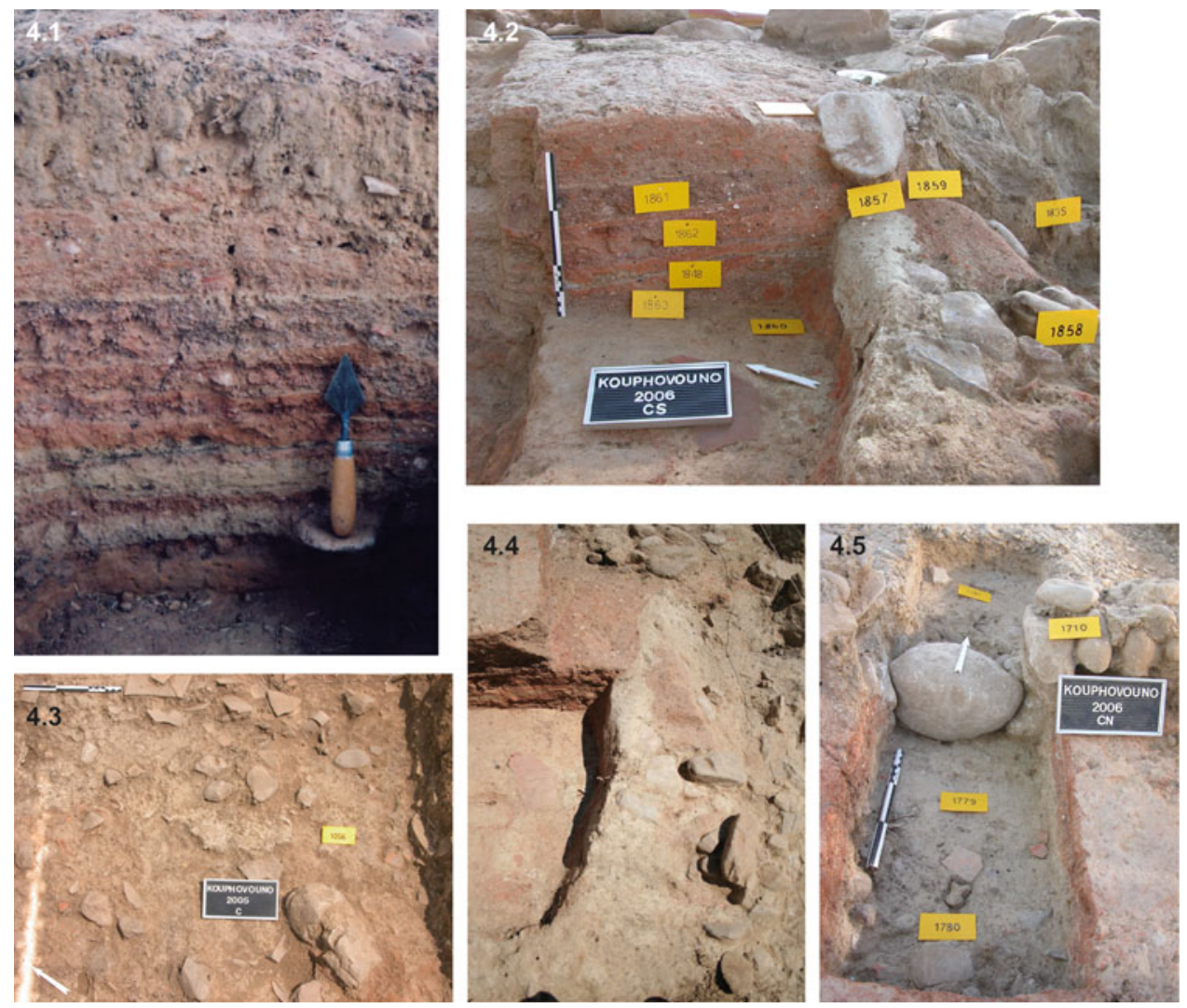

Figure 4. Photographs of burnt levels in Area C. 4.1: Sampled 'millefeuille' excavated in 2005. 4.2: millefeuille, excavations in 2006. 4.3: context 1056, burnt sediment, fragments of limestone, limestone cobbles, fragments and slabs of burnt plaster, and pottery sherds. 4.4: small wall to the south of the 'millefeuille', a lime-covered clay rendering and stones. 4.5: sounding located to the south of wall 1710 (excavation ceased at level 1780), and red level sampled (photographs: C. Ballut).

Furthermore, a W-E section was cut over a length of $1 \mathrm{~m}$ into the upper layers on the south side of the 'millefeuille' to trace the line of the wall towards the east. The boundary marked by the wall continued in this direction, as indicated by a limecovered clay rendering and stones (Figure 4.4). In sum, roughly $2 \mathrm{~m}^{2}$ of the upper layers of the reddened area were removed and $0.5 \mathrm{~m}^{2}$ of the lower layers.

No interpretation of this structure was suggested during its excavation. Only in the light of the micromorphological analyses could the interpretation put forward here be developed.

\section{Micromorphological Study}

\section{Methodology}

Several previous studies have demonstrated the potential of soil micromorphology analysis for the investigation and identification of tell sediments. They have considered firing structures (Germain-Vallée et al., 2011) or procedures for the preparation of building materials in Greece (Bookidis, 1999; Karkanas, 2006; 2007; Karkanas \& Stratouli, 2008; Karkanas \& Efstratiou, 2009), Bulgaria (Brochier, 1994), and Cyprus (Hourani, 2003). 
Among the samples taken for micromorphological analysis at Kouphovouno, two burnt areas were targeted. Four samples were taken from the section cut through the socalled 'millefeuille' in Area C $(42 \mathrm{~cm})$. The four samples overlapped from the base to the top so as to be sure to include the whole section. Another sample was taken outside the 'millefeuille', to the south of wall 1710 (Structure C2). This last section consisted of a single red and burnt layer and a carbonate layer below (Figure 4.5). We could observe the sediment in and below the reddish surface, but not the sediment above, which was destroyed by ploughing. This second sample serves for comparison with the 'millefeuille'. The aim was to obtain comparable data from the two locations to investigate the different hypotheses suggested.

Cubes of sediment were extracted with a knife and a trowel. They were reinforced with plaster strips to protect them in transit. The samples were prepared using standard techniques at the EPOC laboratory (UMR 5805 CNRS/Bordeaux 1, France). Largeformat thin sections were obtained $(6 \times 13$ $\mathrm{cm})$. They were analysed at the $\mathrm{ArScAn}$ laboratory (UMR 7041, Nanterre, France) following the international standard chart for soil thin sections (Bullock et al., 1985; Courty et al., 1989). They were analysed with a Leica microscope with $1.6 \times$ to $400 \times$ magnifications, under plane-polarized (PPL) and cross-polarized (XPL) light. The microcomponents, the micro-structures, the relationships between them in each layer and between the different layers were identified, and hence the form and function of the materials, in particular before they were burnt.

\section{Results}

\section{The 'millefeuille'}

Four thin sections (from bottom up: 2005-P8, P7, P6, P5) showed alternating reddish and whitish layers from Area $\mathrm{C}$ as described above (Figure 5). The succession and alternation between red and white layers were regular. They presented horizontal and parallel boundaries at the macroscopic scale.

The reddish sediments (seven main layers observed) were the thickest (2-7 $\mathrm{cm})$. Their sedimentary composition consisted of an accumulation of red, orange, or black sandy loam aggregates (sand: 20 per cent). The degrees of firing (masked birefringence, sand grains rubified, opacity, cracks) were very different from one aggregate to another and explain the differences in colour. The internal structure of the aggregates was compact and homogeneous. In most cases, they were small (a few $\mathrm{mm}$ ), rounded, and thoroughly weathered. In thin sections P6 and P5, several larger aggregates $(2-3 \mathrm{~cm})$ showed relict plant shapes (curved phytoliths, 30 per cent) indicating a kneaded material with plant components added as a binder. Some presented planar surfaces (evidence for their fabrication). In the red layers the porosity was variable (20-50 per cent) due to the greater or lesser compaction of the deposit. Some accumulations of ash and several charcoal fragments were also noted. No other cultural remains were observed inside. These reddish layers were formed by an accumulation of building materials that were more or less fragmented and burnt, with or without plant components. They always presented the same characteristics, even if the depth of the layer and the size and colour of the aggregates varied. Each corresponded to a single bulk deposit (Figure 6.1).

The whitish sediments did not always present the same characteristics. At the bottom of the sounding (P8 and base of P7), the lowermost two white layers (1069 and 1065) were thicker $(4 \mathrm{~cm})$ than those at the top ( $1 \mathrm{~cm}$ on average) and exhibited significant differences. These two layers 


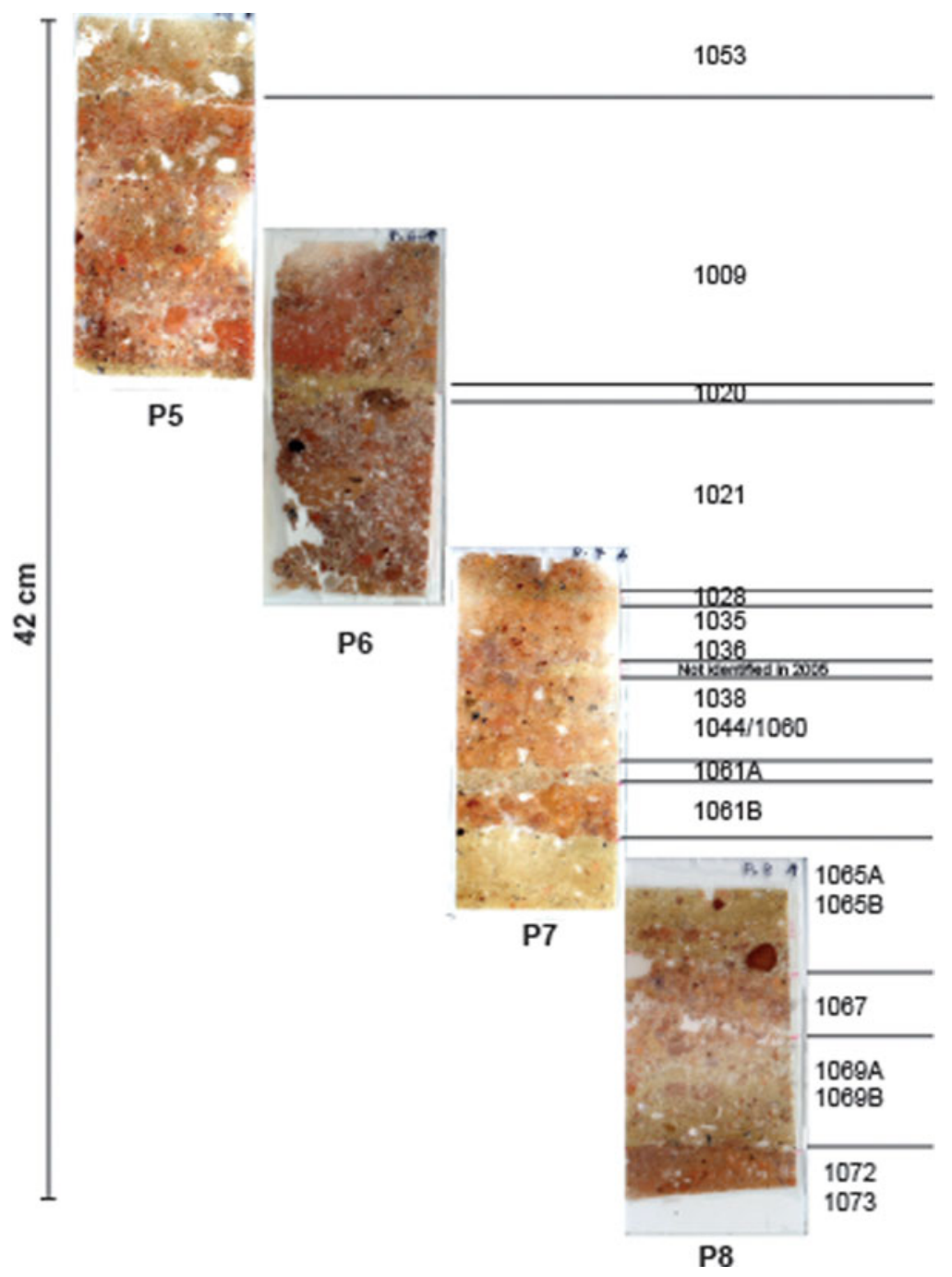

Figure 5. The four thin sections obtained from the 'millefeuille' in Area $C$ (photographs: C. Ballut).

had two components each, lower (B) and higher (A). The lower components (1069B, 1065B) were $2 \mathrm{~cm}$ thick and consisted of loam and carbonate. They incorporated burnt as well as unburnt calcareous micro-fragments, millimetresized red aggregates, and charcoal. The burnt calcareous micro-fragments were grey, isotropic, and sand-sized (Figures 6.2 and 6.3), indicating the presence of lime. Lime is difficult to distinguish from natural carbonate sediment in calcareous contexts and it is only lime lumps such as these that can prove its presence (Bookidis, 1999; Karkanas, 2007). They constituted 10 per cent of the level on average. These components were packed together with a low porosity (10-20 per cent) and presented horizontal voids on the same orientation. This structure was particularly clear in the upper of the two deposits and was probably due to trampling. The upper components of these two layers $(1069 \mathrm{~A}, 1065 \mathrm{~A})$ were also $2 \mathrm{~cm}$ 

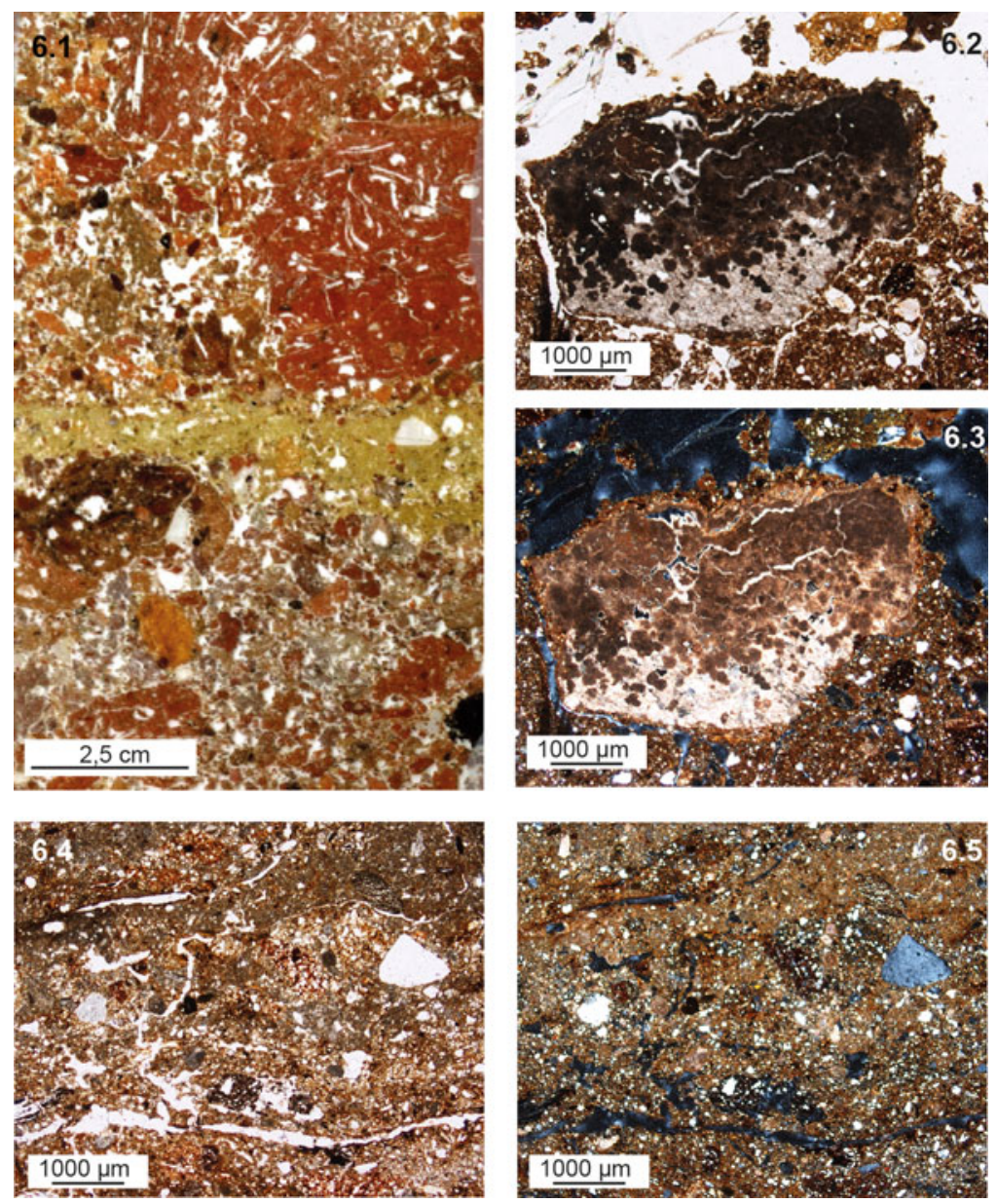

Figure 6. Details of the 'millefeuille' in Area C. 6.1: close-up of P6. Two red layers (accumulation of building materials more or less fragmented and burnt, with or without plant components) separated by a whitish layer. 6.2 (PPL) E 6.3 (XPL): grey, isotropic, and sand-sized burnt calcareous microfragments, lime lump in whitish layer. 6.4 (PPL) \& 6.5 (XPL): accretion of carbonate aggregates in a whitish layer due to trampling (photographs: C. Ballut).

thick, loamy, and contained carbonates (numerous micritic crystallizations). They incorporated only burnt calcareous microfragments (20-30 per cent), taller red aggregates $(1 \mathrm{~cm})$, and occasional charcoal. These components were more homogeneous than the sediment below, composed of carbonates, without organization, and not packed. The porosity was higher (2030 per cent), and the contact with the next red layer above did not form a regular boundary. In this it differed with the white layer observed higher up. The upper components of the two white layers (i.e. 1069A and 1065A) were not compacted. This deposit of lime had not been trampled.

Further up, the upper whitish sediments (four main layers observed) were $1 \mathrm{~cm}$ thick on average. The matrix was composed of fine micritic carbonates and incorporated some lime lumps. These fragments were not numerous (one or two per layer) but indicate that lime powder 
could be a main component. The sediment also incorporated small reddish and isolated aggregates, and some bone and charcoal micro-fragments. The regular surfaces of the levels, the packing of the aggregates (low porosity: 10-20 per cent), the horizontal porosity and, sometimes, the internal stratification indicate trampling. Locally, some beds and accumulations of graded sands showed the effects of rain on the soil. These layers were formed essentially by accretion of carbonate aggregates due to trampling carried out in an open-air area (Figures 6.4 and 6.5).

The top white layer (top of P5) was somewhat different. The sediment was still loamy carbonate, and incorporated red aggregates, a piece of pottery, and some burnt and unburnt calcareous micro-fragments. The porosity rose to 30 per cent. There was no organization in the sediment due to trampling. It was a new bulk deposit with components of various origins. The top of this layer was not observed.

\section{Comparison with the red level near the south wall of Structure C2}

A separate sample (2006-P2) was taken from the sediments situated against the southern outer wall of Structure C2 (context 1710). Macroscopic inspection of this sample indicated a reddened layer resting on top of a sediment of carbonate (Figure 4.5). Analysis of the thin section revealed the details of this stratigraphy and showed four stages from bottom to top (Figure 7.1). They were completely different in character from the sequence observed in the 'millefeuille'.

The first complex $(3.5 \mathrm{~cm}$; Figure 7.1.1) was composed of a brown, clear, sandy loam and carbonate sediment with some iron staining, calcareous gravels, and lime lumps (sand-sized, 20-30 per cent) (Figure 7.2). We also noticed other small and infrequent aggregates. Some of them were brown-grey and loamy to sandy loam (2-3 $\mathrm{mm}$ maximum). Others were red (burnt) and loamy clay $(<1 \mathrm{~mm})$. Porosity was low, in residual cavities (10-15 per cent). The numerous sub-horizontal voids inside the layer showed compaction but they did not exhibit a specific organization due to trampling. This was a constructed surface with the inclusion of lime in notable quantities that seems to represent a true cementing binder (Karkanas, 2007). This first complex corresponds to context 1780 in the excavation, which presents the same characteristics (Table 1, SD).

The second complex (Figure 7.1.2) was composed of three layers separated by horizontal and irregular boundaries. The lowest layer was a brown-red, sandy loam, carbonate, and oxidized sediment $(1 \mathrm{~cm})$. It included red burnt micro-aggregates a few millimetres in size and a fragment of hearth floor (sandy loam, arcuate channel porosity, kneaded). An accumulation of ash was observed in places. Porosity was low (10 per cent). The next layer $(2 \mathrm{~mm})$ presented micro-aggregates similar to the sediment observed below (50 per cent), fused with charcoal at a sub-horizontal angle (burnt twigs) and much ash (50 per cent). Finally, a white deposit of wood ash (3-4 mm) was noted (Figure 7.3). It included accumulations of burnt animal hair (Figure 7.4). Some brown and sandy loam aggregates were also incorporated. The three layers of this sequence were mainly formed by accretion due to trampling around a fireplace (packed aggregates, low and horizontal porosity). The fragment of hearth floor and the wood ash confirmed the presence of a fireplace, probably for cooking.

Two thicker and lighter-coloured layers made up the third complex (Figure 7.1.3). The first deposit $(1 \mathrm{~cm})$ was composed of small, rounded aggregates (a few $\mathrm{mm}$ ). Most of them were red and sandy loam (sand: 30-40 per cent). They were burnt, fragmented, and difficult to interpret. 

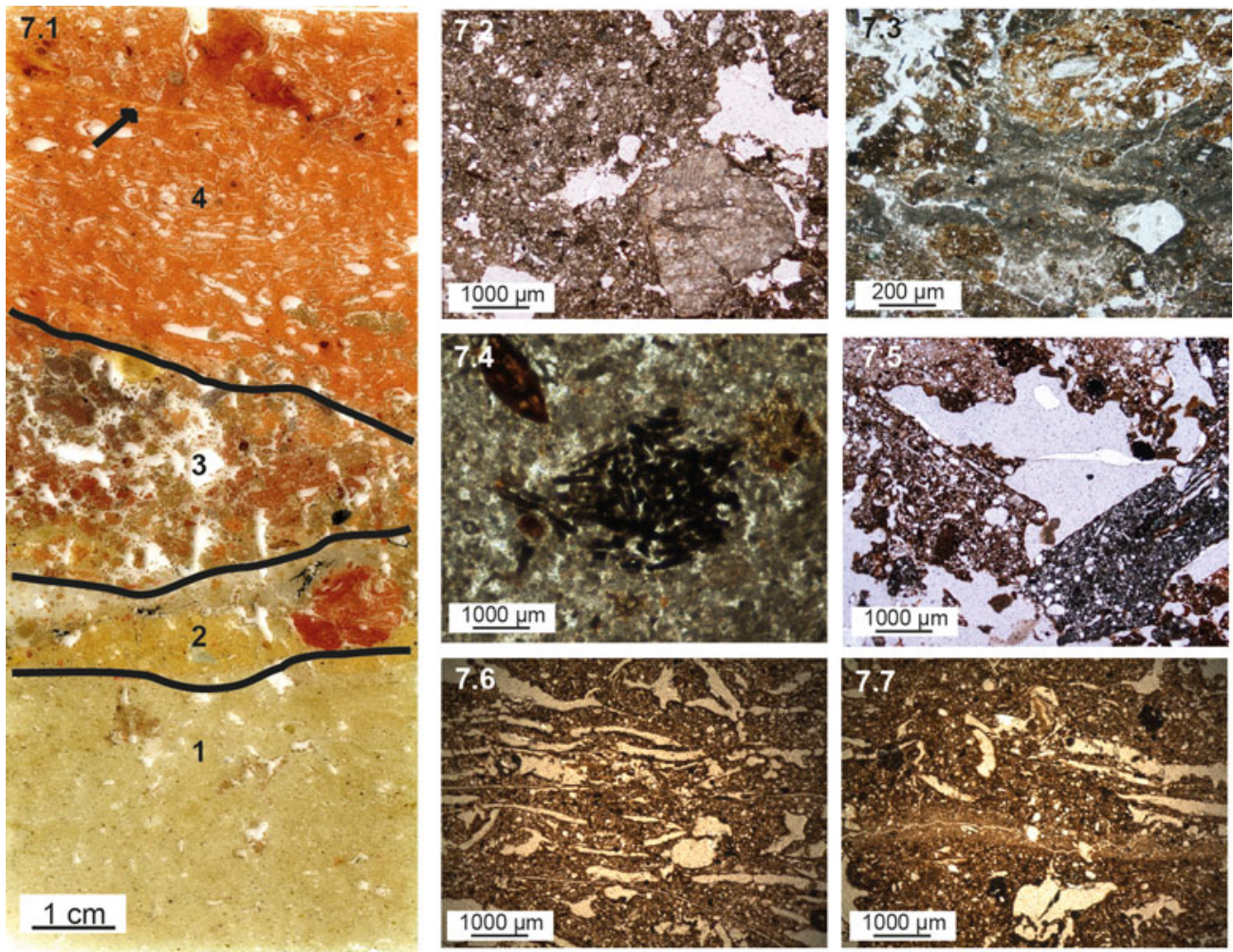

Figure 7. Thin section 2006-P2. 7.1: thin section 2006-P2 and its four components. The arrow points to a fine sandy line. 7.2: lime lump in a well prepared sediment composed of a brown clear, sandy loam and carbonate sediment with some iron staining and calcareous gravels (component 1 of thin section illustrated in 7.1). 7.3: ashy deposits with horizontal and irregular boundaries and incorporation of aggregates by trampling (component 2). 7.4: accumulation of burnt animal hair in an ashy layer. 7.5: burnt pieces of earth constructions, aggregates with horizontal planes and without relict plant shapes (component 3). 7.6: detail of the burnt red kneaded and sandy loam sediment with some relict plant shapes (component 4). 7.7: fine linear layer $(1 \mathrm{~mm})$ of beige, carbonate and sandy sediment between two aggregates (component 4) (photographs: C. Ballut).

They were in a brown, loamy to sandy loam and high carbonate matrix (40 per cent). A few accumulations of yellow ash were also observed. The next layer above was $1-2 \mathrm{~cm}$ thick. Larger, red or black, rounded and broken aggregates appeared. They had the same characteristics but were more burnt than the fragments of the previous layer. Some of them showed a horizontal orientation with an internal parallel porosity and seemed to be 3-4 $\mathrm{mm}$ thick (Figure 7.5). A fragment of charcoal (a few $\mathrm{mm}$ ) and some ash were also observed. The carbonate and loamy matrix between these components was reduced (10 per cent).

The last complex $(5 \mathrm{~cm}$; Figure 7.1.4) was composed of two red and sandy loam layers or aggregates (sand: 30 per cent). They extended over the whole width of the thin section $(6 \mathrm{~cm})$ and were bounded by horizontal planes. They presented some relict plant shapes looking like curved phytoliths (30 per cent) indicating a kneaded sediment (Figure 7.6). The more marked oxidizations around the voids and the lack of cracks showed that the sediment was burnt less severely than the fragments 


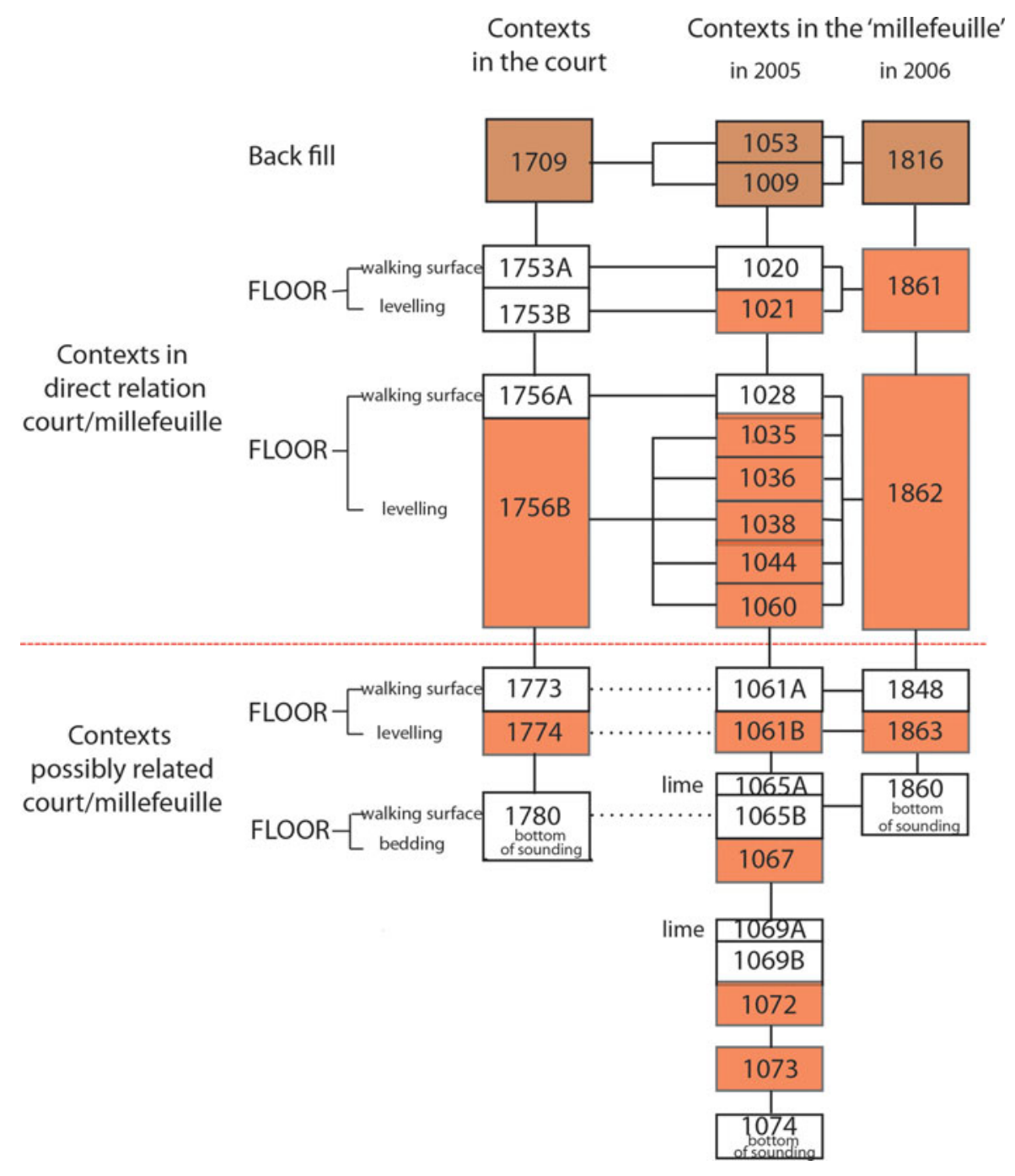

Figure 8. Stratigraphic sequence (Harris matrix) (graphics: J. Renard).

observed on the top of the third sequence. The two layers were separated by a fine horizontal layer $(1 \mathrm{~mm})$ of beige carbonate and sandy sediment (Figure 7.7). We could not report the depth of the lowest layer, but the upper was $3 \mathrm{~cm}$ thick.

\section{Interpretation}

The red deposits of the 'millefeuille', just like those of the sample taken close to wall
1710 of Structure C2, were located in a courtyard. They both have in common a silty clay composition or burnt building materials, i.e. a silty clay to which water and fillers had been added. The shape and size of the largest aggregates observed in the sample taken close to wall 1710 suggest that in this location silty clay coils were prepared with a plant filler. The fine horizontal layer between the coils is probably the remains of a fine sand sediment accumulating where the coils had been 
deposited after they were made. However, not all the elements that were to make up the red layers examined showed traces of phytoliths. Among the samples taken close to wall 1710 , some fragmentsalmost black, severely burnt, a few $\mathrm{mm}$ in height, and with an internal laminationcould derive from a plaster lacking a plant filler. In the 'millefeuille' too, the aggregates of burnt built material do not always include a plant filler. Moreover, the red sediments near the wall were not all deposited on a single occasion, whereas in the 'millefeuille' each red level corresponded to a much more homogeneous deposition.

The white deposits below the red level beside wall 1710 was a prepared floor (context 1780), a homogeneous combination of aggregates of different origins, 30 per cent of them lime lumps. It was compacted rather than trampled, which indicates that the floor in this area had a permanent covering.

For their part, the white deposits in the 'millefeuille' contained much more carbonate. The thinner layers were clearly trampled sediments and the lime lumps were much less common than in the prepared floors recognized elsewhere on the site (up to 10 per cent aggregates). The thicker examples had at the top (1069A, $1065 \mathrm{~A})$ a second phase that was not trampled or compressed and in which, unlike the prepared floors, there was no admixture of materials of different origins; the lime lumps were more prominent here (20-30 per cent) and incorporated into a level which contained only carbonate sediment. Larger calcareous fragments were also observed macroscopically in these layers (these were not sampled in blocks). Hence we conclude that it was pure lime. These last phases were immediately covered by debris consisting of burnt building material that was not trampled, which suggests that the two deposits followed one another in quick succession. Note that in the 'millefeuille' white levels, the micritic crystallizations were so numerous that it was often difficult to distinguish possible ash from lime powder.

The elements forming the sediments sampled close to wall 1710 probably belong to the remains of a destroyed oven/ hearth set on a prepared floor (complexes 2 and 3 above) and a dome made of clay coils (complex 4 above). The 'millefeuille', to judge from its height and the uniformity of the layers of which it was composed, implies a regular, recurrent activity involving a firing phase, a dismantling phase, and a trampling phase.

\section{Discussion}

Firing in a covered clamp is a technique of firing whereby the load is arranged in a stack and covered by an impermanent structure, the 'mantle'; the latter is composed either of pottery sherds or lumps of earth, or in the form of wattle and daub, or sometimes even a combination of these elements. Animal dung is also sometimes used to cover the clamp. The firing site is generally placed on the ground surface, sometimes in a slight hollow, and the pottery to be fired, previously dried in the open air, can be placed on stones, which reduces direct contact with the fuel laid at the bottom of the structure. Openings in the mantle allow air to circulate, and they can, at will, be opened or closed to move from an oxidizing to a reducing atmosphere. While quite similar to a kiln, it need not be viewed either as an enhanced bonfire or as a primitive form of kiln (Livingstone-Smith, 2001; Thér, 2004). Once firing is over, the mantle is broken up to recover the pottery, and then the fragments of the mantle are scattered over and near the firing site, or simply dumped or even recycled. These temporary 
structures leave few or no archaeological traces and it would probably be misleading to attempt to compare them with the remains of permanent installations, such as that at Imvrou Pigadi, which arise from a different operation and technology. Our intention here is to discuss whether the remains of the 'millefeuille' structure described above tally with a covered clamp.

\section{Compatibility of firing in a covered clamp with the production of MN pottery}

Contrary to the standard view, which maintains that only firing in a permanent structure such as a potter's kiln allows the temperature required for high quality pottery (such as the Urfirnis pottery of the MN period) to be achieved, it has been clearly demonstrated that, even in open-air fires, high temperatures in excess of $900^{\circ} \mathrm{C}$ and comparable with those obtained in a kiln can be reached (Gosselain, 1992; Livingstone-Smith, 2001). Since we know that the firing temperature of Urfirnis pottery is around $800-850^{\circ} \mathrm{C}$ (Vitelli, 1997), it follows that firing in a clamp, a fortiori in a covered clamp, is compatible with the production of MN pottery, including Urfirnis.

One objection against firing in an impermanent installation such as a covered clamp concerns the contact between the charge to be fired and the fuel (Vitelli, 1997). This objection cannot be sustained, given the various procedures available to position a charge in a clamp relating to the type of pot (at the base of the clamp, towards its interior or exterior, using larger vessels to hold smaller pots inside the clamp), and the various ways to arrange the fuel-below the clamp, around it, inside or on top of it, according to type (wood, branches, leaves, straw, animal dung, etc.). Note that firing circles have been found at Franchthi, Lerna, and Kouphovouno, indicating that pots were sometimes fired in a stack (Vitelli, 1993: 199-201; 2007: 95; Loughlin, 2010: 109). The technique can be used in bonfires as well as in more elaborate pottery firing installations.

Ethnographic studies from the Mediterranean area have referred to the use of bonfires in pottery production or to the use of kilns, but not to firing in covered clamps (e.g. Crane, 1988; London, 1989). Ethnographic parallels clearly show that potters are not subject to fixed rules; rather, each individual applies his or her own expertize at every stage of the process of manufacture, in relation to both the environment and the desired outcome (e.g. Kramer, 1985 with references; Costin, 2000 with references). While ethnographic comparanda are certainly not to be taken at face value, nonetheless they help clarify for us the expertize and objectives of potters from another age.

\section{The reddened levels of the 'millefeuille'}

The layers of reddened sediment led us to rule out straight away simple bonfire firing because in this type of construction the charge to be fired, which rests directly on the fuel, is covered only by the fuel, whereas we observed remains of a construction (Rice, 1987; Thér \& Gregor, 2011). On the other hand, firing using a protected bonfire (Agumba \& Abbott, 1996) would be a contender because the low wall of clay, which protected and delimited the base of the clamp, could bake during the firing and, once destroyed, be compacted to form a layer of reddened sediment. However, we rejected this hypothesis because this type of firing, like the simple bonfire, allows little control of either temperature or firing atmosphere (oxidizing or reducing), two requirements indispensable for producing pottery such as Urfirnis. 
The reddened layers are formed of burnt deposits essentially made up of construction materials, with a very small amount of ash and charcoal. We interpret them as the remains of a mantle from an open-air firing area and we can propose three possibilities regarding its form.

In the first scenario, the mantle is formed from a framework made of wood plastered with a clay sediment often enriched with a filler to make it more malleable and better for construction. This hypothesis is corroborated by the archaeological remains found within the 'millefeuille', for example a fragment of burnt building clay bearing the impression of a piece of wood in the red context 1021 as well as numerous fragments of red sediment bearing impressions of cut vegetation such as straw. The thin sections themselves revealed phytoliths, which indicates that the kneaded clay contained plant matter. A number of thin sections showed aggregates with planar surfaces which could have arisen from smoothing building clay plastered onto a wooden framework. Architectural parallels were found at Kouphovouno; they are consistent with this mode of construction combining wood and building clay. It must, however, be made clear that the traces of plant filler appearing in negative on the fragments of true clay building material are much more abundant than those recognizable in the remains of the mantle. This suggests that the red deposits in the 'millefeuille' did not come from the destruction of buildings as had originally been supposed. In this first model, it would be possible to adapt the mantle for specific interventions, be it at the base or at the top, to add extra fuel or to regulate the firing atmosphere by opening or closing it.

The second hypothesis proposes a mantle formed by a belt of raw clay moulded into bricks or formed into sods (Roy, 2008)-through which openings would allow the introduction of extra fuel or ventilation-and a covering 'roof of branches plastered with building clay. The archaeological traces such a structure would leave would appear to be essentially the same as those of the first hypothesis. In this second scenario the planar surfaces on certain aggregates would have originated from the bricks or sods of clay. Note, however, that no complete brick has been found in the Neolithic deposits excavated at Kouphovouno, either in an architectural or in a destruction context. On the other hand, the technique of building a timber structure filled with sods of earth is attested.

The third hypothesis would envisage the wall discovered to the south of the firing area as a permanent boundary, onto which one could have constructed the mantle, as in the first hypothesis. The mantle could have rested on the wall to the south and directly on the ground elsewhere (Miller, 1997).

In all three scenarios, once the firing of the pottery was complete, the mantle would have been broken up to recover the fired objects and then the mantle's fragments would have been spread across the firing area. Each reddened layer corresponded to a single firing event, as revealed by the thin sections: these do not show any signs of redeposition, suggesting that they were deposited in a single operation.

What, then, was done with these burnt clay remains after firing? We know from ethnographic parallels that the area devoted to firing ceramics, particularly when found within a settlement, for example in a courtyard, is cleaned and returned to being used as an area where people circulated (Arnold, 1990). Note that on our site, close to the 'millefeuille', there was a large dump (the 'rubbish bin', see above) where the remains of these cleaning operations could have been deposited. We should also bear in mind that the remains from firing need not have been dumped; they could have been 
adapted to some other use (Angle \& Dottarelli, 1989). At Kouphovouno the excavations have revealed accumulations of red clay between the houses, part of which we suggest need not have come from buildings destroyed by fire but from the demolition of the mantle. Furthermore, the floors, especially outside but also inside the houses, have reddened traces on their surfaces, and these may have been the remains from spreading the debris of the mantle. How is it, then, that thick red layers ended up in the 'millefeuille', the presumed site of the firing area? Let us consider the stratigraphy of the 'millefeuille' and that of the courtyard to the west of the firing area, where three new floor levels were added after destruction/ trampling/rebuilding of the circulation level. The contexts corresponding to these operations were of a depth that was comparable to that of the reddened layers of the 'millefeuille'; they were also at approximately the same absolute height. It is thus probable that the remains of the mantle were kept and scattered in their totality or in part with a view to maintaining the floor of the courtyard at the same height (Figure 8). Assuming that the firing area was used over the whole of its extent (over about $4 \mathrm{~m}^{2}$ ) at each firing, and supposing that the mantle would have formed a hemisphere about $8 \mathrm{~cm}$ thick (wooden frame and mud plaster, or earth foundation topped by a mantle of mud and wood), we calculate a volume of $0.5 \mathrm{~m}^{3}$ of material. Estimating that the total quantity of wood burnt during the firing was a quarter of that volume, some $0.37 \mathrm{~m}^{3}$ remains to spread over the firing area and its vicinity, which corresponds to a depth of around $9 \mathrm{~cm}$ over a surface of roughly $4 \mathrm{~m}^{2}$. This depth corresponds approximately to the thickest of the reddened deposits (1021 and the sequence made up of 1035, 1036, 1038, 1044, and 1060) in the upper part of the stratigraphic sequence, which are roughly $7 \mathrm{~cm}$ thick. The less thick reddened layers (1863 and 1067 , for example, are roughly $3 \mathrm{~cm}$ thick) found in the lower part of the stratified sequence suggest either that not all of the mantle was spread over the firing area after firing, or that the mantle was smaller.

In brief, in the upper part of the stratigraphy of the 'millefeuille' the remains of the mantle correspond to two relatively major re-levelling episodes of the courtyard (1021 // 1753/54 and 1035-1060 // 1756); in the lower part the shallower depth of the reddened layer 1863 seems to echo the re-levelling 1774 of the courtyard, some $3 \mathrm{~cm}$ thick.

\section{The whitish levels of the 'millefeuille'}

In the 'millefeuille', levels consisting of grey-whitish deposits were found to be in two forms: shallow layers in the upper levels and thicker layers in the lower layers.

The shallow layers (1020, 1028, 1061) had all been trampled. The thicker deposits (1065 and 1069) consisted in fact of two different layers and only the lower one in each case was trampled. In other words, the whitish trampled levels all rested on top of the reddened levels which were not characterized by trampling. We suggest that the shallow trampled levels be identified with trodden surfaces, laid over the firing area when it was no longer in operation. The remains of the roughly scattered and compacted mantle would then have been covered with lime (dusting) to consolidate the floor and make it usable (Gourdin \& Kingery, 1975; Kingery et al., 1988; Hermann \& van Egmond, 1997). It is noteworthy that the trampled surfaces correspond to the trodden surfaces found elsewhere in the courtyard: context 1020 of the 'millefeuille' corresponds to the top of floor $1753 / 54$, context 1028 with the top of floor 1756; moreover, in the small 
sounding to the south of wall 1710 of Structure C2, an extrapolation of the heights would suggest that context 1774 corresponds to context 1061 of the 'millefeuille', and floor 1780 with the lower part of context 1061, which shows traces of trampling. But caution must be exercised because of the distance separating these contexts and we do not propose this interpretation as more than provisional.

The lowest white layer of the 'millefeuille' (1069), separated from 1065 by the reddened deposit 1067 and itself composed of two layers (the lower being a trampled surface), could not be linked with any other context, as the excavation of the sounding in the western part of the courtyard was discontinued before reaching this depth. The composition of the upper layers of the two whitish levels 1065 and 1069 may relate to the (intentional or unintentional) production of lime during the firing of pottery. Some larger pieces of calcareous material have been observed but not sampled in block. As suggested above, the charge was perhaps separated from the floor by stones or cobbles which served to support the vessels and to separate them from the fuel laid on the floor of the courtyard. Even though it is recommended to use fire-proof stones to avoid their burning up during firing, it is possible that limestone (found in abundance on Mount Taÿgetos and in the bed of the River Parori, the stream which bounds the site to the north) was used at Kouphovouno. The temperature needed to reduce limestone to lime could be achieved at $\mathrm{MN}$ Kouphovouno because it is the same as that required for firing Urfirnis pottery, namely $800-850^{\circ} \mathrm{C}$. Lime was used in construction, as attested, for example, by remains of lime plaster on the trampled surface of floor 1718 inside Structure C2, on the outside stone footing of the west wall of Structure C4, on top of the wall bounding the firing area to the south, in destruction deposits, and on surfaced floors such as context 1780. Alternatively, the additional layer of lime 1069A, spread over the trampled floor level 1069B, could represent an accumulation of lime brought in from elsewhere and intended to make plaster for nearby structures but left in situ and unused immediately before the next pottery firing attested by the overlying red deposit (1067). The same procedure could also apply to $1065 \mathrm{~A}$ and $1065 \mathrm{~B}$.

\section{Conclusion}

The combined data recovered from excavation, micromorphological analysis of thin sections from samples taken from the archaeological sediments, and a reconstruction based on recent ethnographic and experimental research, have led us to suggest the presence of an open-air pottery firing area, a covered clamp capable of producing Urfirnis pottery at temperatures in the range of $800-900^{\circ} \mathrm{C}$. In summary, the 'millefeuille' does not record every firing sequence in the area, but only those which happened just before an episode that involved raising the level of the courtyard's floor. The remains of the mantle were not removed on this occasion but were scattered in the material used for refurbishing the level of the courtyard. This burnt clay debris could have been systematically covered with lime, probably to stabilize the surface and to make it more usable. Production of lime observed in the lower part of the 'millefeuille' was probably accidental. At each firing, limestone cobbles were placed on the floor to serve as supports for the charge to be fired and the heat would have converted them to lime. This, at least, is what the two lower firing sequences of the 'millefeuille' suggest.

Could the remains described here represent the remains of a structure designed for another purpose? Or could this 
structure have been used for burning lime rather than firing pottery?

These possibilities merit careful consideration, but there are reasons for rejecting them. Generally, lime burning was carried out at the edge of a site, rather than in courtyards, because of the highly caustic nature of quicklime. On the other hand, the risk of high temperatures notwithstanding, the presence of kilns outside houses and in courtyards, for example at Yarim Tepe (Hansen Streily, 2000: 72), shows that pottery firing was possible in conditions such as those we describe at Kouphovouno. Furthermore, a thorough archaeological investigation of lime burning was carried out at the Pre Pottery Neolithic B (PPNB) site of Kfar HaHoresh by Goren and Goring-Morris (2008). It involved a careful analysis of excavated pits, experimental archaeology, and micromorphological analysis. There, the archaeological remains were very different from those at Kouphovouno: the residues of the lime pits, lying on the edge of the site, contained numerous burnt and fire-cracked limestone cobbles of various sizes roughly piled in and around poorly defined shallow depressions. Moreover, the characteristics of the sediments revealed in micromorphological thin sections had nothing in common with those recovered from the 'millefeuille'. Indeed, firing in open pits is quite satisfactory for producing lime; closed structures, such as those evidenced in the red layers of the 'millefeuille' at Kouphovouno, would be superfluous for reducing lime. For these reasons we believe that the lime burning hypothesis is unconvincing. In any case the construction of a pottery firing installation in the middle of a courtyard would only intermittently serve small groups, in contrast to larger-scale production areas for whole communities.

It is possible that the procedure employed in the various sequences changed over time, as could the construction of the mantle and the form of the firing area. The firing episodes took place over a long period within the settlement, between houses and among various domestic installations, within a courtyard whose floor level was raised from time to time, at the same time as new floors were raised in the houses and nearby. Ideally, it would have been desirable to continue the excavation of Area $\mathrm{C}$ to reveal the full dimensions of this firing area and to define even more precisely its extent and function over time. Unfortunately the archaeological layers are no longer accessible and it is impossible at present to return to verify our findings. The technique of firing pottery in a temporary structure has so far not been discussed in the context of the Middle Neolithic in the Aegean, and this study, based on the excavations at Kouphovouno, will have achieved its aim if it opens fresh lines of enquiry within the framework of new archaeological investigations.

\section{Supplementary Material}

To view supplementary material for this article, please visit https://doi.org/10.1017/ eaa.2016.4.

\section{AcKNOWLEDGMENTS}

The excavations at Kouphovouno are a joint project of the British School at Athens and the École française d'Athènes. They were carried out under the aegis of the $5^{\text {th }}$ Ephoreia of Prehistoric and Classical Antiquities. We would particularly like to thank the members of the Archaeological Service of the Greek Ministry of Culture who helped the progress of our project over many years: Dr E. Kourinou, Dr A. Mantis, Mrs A. Panagiotopoulou, Mrs S. Raftopoulou, 
Mrs E. Rozaki, Dr Th. Spyropoulos, Mr N. Themos, Mrs M. Tsouli, Dr A. Vasiligamvrou, and Mrs E. Zavvou. We are also most grateful to the staff of the British School at Athens for their assistance. The work was funded by the Institute of Aegean Prehistory, the École française d'Athènes, The French Ministry of Foreign Affairs, the Centre National de la Recherche Scientifique, and the Universities of Liverpool, Nottingham, Bretagne-Sud, and Clermont-Ferrand. We also wish to express special thanks to Julia Wattez (INRAP, France), who shared her experience of the study of burnt material in thin section with us, as well as to Thomas Loughlin, who excavated Area C very carefully in 2005 and 2006. We are also most grateful to the anonymous referees who suggested a number of helpful improvements to the text.

\section{REFERENCES}

Agumba, M. \& Abbott, V. 1996. How to Build, Use, and Maintain a Better Bonfire Kiln. Nairobi: Intermediate Technology Kenya.

Aidona, E., Polymeris, G. \& KyparissiApostolika, N. 2014. Middle Neolithic Period: New Archaeomagnetic and Thermoluminescence Data from a Pottery Kiln at Magoula Imvrou Pigadi, SW Thessaly, Greece. Paper presented at the Castle Meeting, New Trends on Paleo, Rock, and Environmental Magnetism, Évora 2014.

Angle, M. \& Dottarelli, R. 1989. Ethnoarchaeology at Uslu (Elazig): A Preliminary Report on Contemporary Manufacture in Eastern Anatolia VII. Arastirma Sonuçlari Toplantisi, 2: 467-79.

Arnold, P.J. 1990. The Organization of Refuse Disposal and Ceramic Production within Contemporary Mexican Houselots. American Anthropologist, 92: 915-32.

Boaretto, E., Wu, X., Yuan, J., Bar-Yosef, O., Chu, V., Pan, Y., Liu, K., Cohen, D., Jiao, T., Li, S., Gu, H., Goldberg, P. \& Weiner, S. 2009. Radiocarbon Dating of
Charcoal and Bone Collagen Associated with Early Pottery at Yuchanyan Cave, Hunan Province, China. Proceedings of the National Academy of Science of the United States of America, 106(24): 9595-600.

Bookidis, N., Hansen, J., Snyder, L. \& Goldberg, P. 1999. Dining in the Sanctuary of Demeter and Kore at Corinth. Hesperia, 68: 1-5.

Brochier, J.L. 1994. Etude de la sédimentation anthropique. La stratégie des ethnofaciès sédimentaires en milieu de constructions de terre. Bulletin de Correspondance Hellénique, 118: 619-45.

Bullock, P., Féderoff, N., Jongerius, A., Stoops, G. \& Tursina, T. 1985. Handbook for Soil Thin Section Description. Wolverhampton: Waine Research Publications.

Cavanagh, W., Mee, C. \& Renard, J. 2004. Sparta before Sparta: Kouphovouno 19992000: Report on the Intensive Survey. Annual of the British School at Athens, 99: 49-128.

Cavanagh, W., Mee, C. \& Renard, J. 2007. Excavations at Kouphovouno, Laconia. Results from the 2001 and 2002 Seasons. Annual of the British School at Athens, 102: 11-101.

Cessford, C. 2007. Level Pre-X II.E-A and Levels Xil and Xl, Spaces 181, 199, and 198. In: I. Hodder, ed. Excavating Chatalboyük: South, North, and KOPAL Area Reports from the 1995-99 Seasons. British Institute of Archaeology at Ankara Monograph. Cambridge: McDonald Institute for Archaeological Research, pp. 59-102.

Çilingiroğlu, Ç. 2012. The Neolithic Pottery of Ulucak in Aegean Turkey: Organization of Production, Interregional Comparisons, and Relative Chronology. British Archaeological Reports International Series 2426. Oxford: Archaeopress.

Costin, C.L. 2000. The Use of Ethnoarchaeology for the Archaeological Study of Ceramic Production. Journal of Archaeological Method and Theory, 7: 377-403.

Courty, M.A., Goldberg, P. \& MacPhail, R. 1989. Soils and Micromorphology in Archaeology. Cambridge: Cambridge University Press.

Crane, H. 1988. Traditional Pottery Making in the Sardis Region of Western Turkey. Muqarnas, 5: 9-20.

Germain-Vallée, C., Prévost-Dermarkar, S. \& Lespez, L. 2011. Stratégies de prélèvement 
et de mise en œuvre de la " terre à bâtir » des structures de combustion néolithiques du site de Dikili Tash (Grèce) à partir d'une étude micromorphologique. ArcheoSciences, 35: 41-63.

Gimbutas, M., Winn, S. \& Shimabuku, S. 1989. Achilleion: A Neolithic Settlement in Central Greece, 6400-5600 BC. Los Angeles: Institute of Archaeology, University of California.

Goren, Y. \& Goring-Morris, A.N. 2008. Early Pyrotechnology in the Near East: Experimental Lime Plaster Production at the PPNB Site of Kfar HaHoresh, Israel. Geoarchaeology, 23: 779-98.

Gosselain, O.P. 1992. Bonfire of the Enquiries. Pottery Firing Temperatures in Archaeology: What For? Journal of Archaeological Science, 19: 243-59.

Gourdin, W.H. \& Kingery, W.D. 1975. The Beginnings of Pyrotechnology: Neolithic and Egyptian Lime Plaster. Journal of Field Archaeology, 2: 133-50.

Hansen Streily, A. 2000. Early Pottery Kilns in the Middle East. Paleorient, 26: 69-81.

Hermann, K. \& van Egmond, B. 1997. Stabilisation à la chaux. Bulletin du ciment, 65: 3-11.

Hourani, F. 2003. Les matériaux de construction en terre à Khirokitia (Chypre): Origines, techniques de préparation et emplois. In: H. Guillaud, H.C.A. de Chazelles \& A. Klein, eds. Echanges transdisciplinaires sur les constructions en terre crue, 1. Table Ronde de Montpellier. Montpellier: Editions de l'Espérou, pp. 161-68.

Huysecom, E., Rasse, M., Lespez, L., Neuman, K., Fahmy, A., Ballouche, A., Ozainne, S., Maggetti, M., Tribolo, Ch. \& Soriano, S. 2009. The Emergence of Pottery in Africa during the 10th Millennium cal BC: New Evidence from Ounjougou (Mali). Antiquity, 83: 905-17.

Karkanas, P. 2006. Late Neolithic Household Activities in Marginal Areas: The Micromorphological Evidence from the Kouveleiki Caves, Peloponnese, Greece. Journal of Archaeological Science, 33: 1628-41.

Karkanas, P. 2007. Identification of Lime Plaster in Prehistory Using Petrographic Methods: A Review and Reconsideration of the Data on the Basis of Experimental and Case Studies. Geoarchaeology, 22: 775-96.

Karkanas, P. \& Efstratiou, N. 2009. Floor Sequences in Neolithic Makri, Greece:
Micromorphology Reveals Cycles of Renovation. Antiquity, 83: 955-67.

Karkanas, P. \& Stratouli, G. 2008. Neolithic Lime Plastered Floors in Drakaina Cave. Annual of the British School at Athens, 103: 27-41.

Kingery, D., Vandiver, P. \& Prickett, M. 1988. The Beginnings of Pyrotechnology Part II: Production and Use of Lime and Gypsum Plaster in the Near East. Journal of Field Archaeology, 15: 219-44.

Kramer, C. 1985. Ceramic Ethnoarchaeology. Annual Review of Antbropology, 14: 77-102.

Kyparissi-Apostolika, N. 2012. Indications of the Presence of Middle Neolithic Pottery Kilns at Magoula Imvrou Pigadi, SW Thessaly, Greece. Documenta Praehistorica, 39: 433-42.

Livingstone-Smith, P.O. 2001. Bonfire II: The Return of Pottery Firing Temperatures. Journal of Archaeological Science, 28: 991-1003.

London, G. 1989. Past Present: The Village Potters of Cyprus. The Biblical Archaeologist, 52: 219-29.

Loughlin, T. 2010. Technological Choice in Middle Neolithic Ceramics from the Peloponnese, Greece. (unpublished $\mathrm{PhD}$ dissertation, University of Liverpool).

Malamidou, D. 2007. Kryoneri: A Neolithic and Early Bronze Age Settlement in the Lower Strymon Valley. In: H. Todorova, M. Stefanovich \& G. Ivanov, eds. The Struma/Strymon River Valley in Prehistory. Proceedings of the International Symposium 'Strymon Praehistoricus', Kjustendil-Blagoevgrad (Bulgaria) and Serres-Amphipolis (Greece), 2004. In the Steps of James Harvey Gaul, vol. 2. Sofia: Gerda Henkel Stiftung, pp. 297-308.

Mee, C. 2007. The Production and Consumption of Pottery in the Neolithic Peloponnese. In: C. Mee \& J. Renard, eds. Cooking up the Past: Food and Culinary Practices in the Neolithic and Bronze Age Aegean. Oxford: Oxbow Books, pp. 20024.

Mee, C., Cavanagh, W. \& Renard, J. 2014. The Middle-Late Neolithic Transition at Kouphovouno. Annual of the British School at Athens, 109: 65-95.

Miller, H. 1997. Pottery Firing Structures (Kilns) of the Indus Civilization during the Third Millenium B.C. In: P. Rice \& D. Kingery, eds. Prehistory and History 
of Ceramic Kilns. Westerville (OH): The American Ceramic Society, pp. 41-71.

Moorey, R. 1994. Ancient Mesopotamian Materials and Industries: The Material Evidence. Oxford: Clarendon Press.

Perlès, C. 2001. The Early Neolithic in Greece: The First Farming Communities in Europe. Cambridge: Cambridge University Press.

Petrova, N.Y. 2012. A Technological Study of Hassuna Culture Ceramics (Yarim Tepe I Settlement). Documenta Praebistorica, 39: 75-82.

Renard, J. 1989. Le site néolithique et helladique ancien de Kouphovouno (Laconie). Fouilles de O.-W. von Vacano 1941. Aegaeum 4. Liège: Université de l'Etat à Liège.

Rice, P.M. 1987. Pots and Potters: Current Approaches in Ceramic Archaeology. Los Angeles: Institute of Archaeology, University of California.

Rivals, F., Gardeisen, A. \& Cantuel, J. 2011. Domestic and Wild Ungulate Dietary Traits at Kouphovouno (Sparta, Greece): Implications for Livestock Management and Palaeoenvironment in the Neolithic. Journal of Archaeological Science, 38: 528-37.

Roy, C. 2008. Making African Pots. Photograph available on Saharan Vibe <http:// saharanvibe.blogspot.fr/2008/12/makingafrican-pots.html> [accessed 19 May 2016].

Souvatzi, S. 2008. A Social Archaeology of Household in Neolithic Greece: An Anthropological Approach. Cambridge: Cambridge University Press.

Thér, R. 2004. Experimental Pottery Firing in Closed Firing Devices from the NeolithicHallstatt Period in Central Europe. euroREA, 1: 35-82.

Thér, R. \& Gregor, M. 2011. Experimental Reconstruction of the Pottery Firing Process of Late Bronze Age Pottery from North-Eastern Bohemia. In: S. Scarcella, ed. Archaeological Ceramics: A Review of Current Research. British Archaeological Reports International Series 2193. Oxford: Archaeopress, pp. 128-42.

van As, A., Jacobs, L. \& Nieuwenhuyse, O.P. 2004. Early Pottery from Late Neolithic Tell Sabi Abyad II, Syria. Journal of Pottery Studies, 20: 97-110.

Vitelli, K.D. 1993. Franchthi Neolithic Pottery, Volume 1: Classification and Ceramic Phases 1 and 2. Excavations at Franchthi Cave, Greece. Bloomington \& Indianopolis: Indiana University Press.
Vitelli, K.D. 1997. Inferring Firing Procedures from Sherds: Early Greek Kilns. In: P. Rice \& D. Kingery, eds. Prehistory and History of Ceramic Kilns. Westerville $(\mathrm{OH})$ : The American Ceramic Society, pp. 21-40.

Vitelli, K.D. 2007. Lerna, a Preclassical Site in the Argolid V: The Neolithic Pottery from Lerna. Princeton: American School of Classical Studies at Athens.

Yiouni, P. 1996. The Early Neolithic Pottery. In: K. Wardle, ed. Nea Nikomedeia I. London: British School at Athens, pp. 55-209.

\section{Biographical Notes}

Christèle Ballut obtained her $\mathrm{PhD}$ in 2000 at the University of Limoges. She is a researcher at the CNRS-Universities of Paris I and X, specializing in geoarchaeology and landscape archaeology.

Address: ArScAN (UMR7041), 21 allée de l'université, 92023 Nanterre, France. [email: christele.ballut@univ-bpclermont.fr]

Josette Renard obtained her PhD in 1991 and her habilitation (HDR) in 2001 at the University of Paris I. She is Professor emeritus of Mediterranean Archaeology at the University of Montpellier III, specializing in Aegean archaeology, architecture, and technology.

Address: ArScAn (UMR7041), 21 allée de l'université, 92023 Nanterre, France. [email : alepo@free.fr]

William Cavanagh obtained his $\mathrm{PhD}$ in 1977 at the University of London. He is Professor emeritus of Aegean archaeology at the University of Nottingham, specializing in Aegean archaeology, mortuary archaeology, and mathematics and archaeology. 
Address: Centre for Spartan and Peloponnesian Studies, University of Nottingham, University Park, Nottingham, NG7 2RD, UK. [email: bill.cavanagh@nottingham.ac.uk]

Raphaël Orgeolet obtained his $\mathrm{PhD}$ in 2008 at the University of Montpellier. He is Assistant Professor of Mediterranean Bronze
Age archaeology at the University of AixMarseille, specializing in Aegean archaeology, architecture, site organization, and society.

Address: Aix-Marseille Université, CNRS, Ministère de la culture et de la communication, LAMPEA UMR 7269, 13094, Aix-enProvence, France. [email: rorgeolet@yahoo.fr]

\section{Structures de cuisson de la céramique en Méditerranée ancienne : données micromorphologiques et archéologiques provenant du site Néolithique Moyen de Kouphovouno en Grèce méridionale}

Les fouilles du site de Kouphovouno (Laconie, Grèce) ont révélé des dépôts brûlés associés à des structures de combustion. Le 'millefeuille' observé était composé d'une alternance de couches rouges brûlées et blanches carbonatées. Sa description archéologique, son analyse micromorphologique et sa comparaison avec une structure plus classique du Néolithique Moyen nous conduisent à linterpréter comme un dispositif de cuisson de la céramique en meule chapée. Son étude nous a permis de préciser ses modalités constructives, son fonctionnement et son utilisation en contexte domestique. Bien que la production de céramique et de chaux ait laissépeu de traces directes, cette activité pyrotechnologique est sans doute celle qui, après le chauffage et la cuisson alimentaire, a consommé le plus d'énergie chez les communautés néolithiques. Nous proposons ici une nouvelle approche pour identifier des structures de cuisson céramique. Mais si la cuisson céramique semble l'usage le plus probable pour le type de structure que nous décrivons, nous discutons également la production de chaux.

Mots-clés: Néolithique, Grèce, four temporaire couvert, construction en terre, micromorphologie

\section{Strukturen zum Brennen der Keramik im frühen Mittelmeerraum: mikromorphologische und archäologische Angaben aus der mittelneolithischen Siedlung von Kouphovouno in Südgriechenland}

Ausgrabungen in Kouphovouno in Lakonien (Griechenland) haben verbrannte Schichten in Zusammenhang mit einer Brennstruktur entdeckt. Die Schichten, die wie in einem "Blätterteig" aufgeschichtet waren, waren alternierend rot gebrannte Aggregate und weiße Karbonate. Die Beschreibung ihrer Eigenschaften, mikromorphologische Untersuchung, sowie ein Vergleich mit einer üblicheren Struktur des Mittelneolithikums ermöglicht es, diese Schichten als Teil einer Brennstruktur zu deuten. Es handelt sich um einen Meiler. Unsere Analyse bat seine Bauweise, seinen Betrieb und seinen Gebrauch im Rahmen einer Siedlung verdeutlicht. Neben Heizen und Kochen ist die Herstellung von Keramik und Kalk die pyrotechnische Tätigkeit, die bei den neolithischen Gemeinschaften am meisten Energie verbrauchte. Jedoch gibt es sehr wenige direkte Beweise, dass es solche Einrichtungen gab. Die Frage der Identifizierung von solchen Brennstätten wird hier neu angesprochen. Das Brennen von Keramik ist die wahrscheinlichste Deutung für diesen Typ von Struktur, obschon die Herstellung von Kalk auch in Betracht gezogen wurde. Translation by Madeleine Hummler

Stichworte: Neolithikum, Griechenland, gedeckter Meiler, Erdbau, Mikromorphologie 